\title{
Pharmaceutical policies for diseases related to poverty in Brazil: a review
}

\author{
Políticas farmacêuticas para doenças relacionadas à pobreza no Brasil: uma revisão \\ Políticas farmacéuticas para enfermedades relacionadas con la pobreza en Brasil: una revisión
}

Received: 10/05/2021 | Reviewed: 10/11/2021 | Accept: 10/11/2021| Published: 10/13/2021

\author{
Rafael Santos Santana \\ ORCID: https://orcid.org/0000-0003-4481-210X \\ Universidade de Brasília, Brasil \\ E-mail: rafael.santana@unb.br \\ Helaine Carneiro Capucho \\ ORCID: https://orcid.org/0000-0002-5438-7963 \\ Universidade de Brasília, Brasil \\ E-mail: helaine.capucho@unb.br \\ Silvana Nair Leite \\ ORCID: https://orcid.org/0000-0002-5258-9684 \\ Universidade Federal de Santa Catarina, Brasil \\ E-mail: silvana.nair@hotmail.com
}

\begin{abstract}
The "epidemiological transition" has fostered increasing attention to chronic and non-communicable diseases, but neglected diseases are still present and their relationship with the population's socioeconomic inequalities is increasingly evident, so much so that there has been a conceptual conversion to call them "poverty-related diseases". It is a necessary to review and to discuss the characteristics and challenges of Brazilian pharmaceutical policies for populations affected by diseases related to poverty. This review of the literature was carried out, with works of the last 10 years dealing with the theme and the Brazilian reality. Out of the 272 identified articles, only 43 publications were included in this study. The results were: (i) the difficulties of investing in the research, development and production of new drugs for these diseases; (ii) the characteristics of access policies to medicines already available, their advances and limitations; (iii) and issues related to the right to comprehensive pharmaceutical assistance. Therefore, for the available therapies, national production and federal funding contributed to guarantee the supply. Assisted qualification actions are necessary and little discussed in area studies.
\end{abstract}

Keywords: Neglected diseases; Health equity; Pharmaceutical services; Health vulnerability.

\section{Resumo}

A "transição epidemiológica" tem fomentado cada vez mais atenção às doenças crônicas e não transmissíveis, mas as doenças negligenciadas ainda estão presentes e sua relação com as desigualdades socioeconômicas da população é cada vez mais evidente, tanto que houve uma conversão conceitual para chamá-las de "pobreza doenças relacionadas ". É necessário revisar e discutir as características e desafios das políticas farmacêuticas brasileiras para populações afetadas por doenças relacionadas à pobreza. Foi realizada esta revisão da literatura, com trabalhos dos últimos 10 anos tratando do tema e da realidade brasileira. Dos 272 artigos identificados, apenas 43 publicações foram incluídas neste estudo. Os resultados obtidos foram: (i) as dificuldades de investir na pesquisa, desenvolvimento e produção de novos medicamentos para essas doenças; (ii) as características das políticas de acesso aos medicamentos já disponíveis, seus avanços e limitações; (iii) e questões relacionadas ao direito à assistência farmacêutica integral. Portanto, para as terapias disponíveis, a produção nacional e recursos federais contribuíram para garantir o abastecimento. Ações de qualificação assistida são necessárias e pouco discutidas nos estudos da área.

Palavras-chave: Doenças negligenciadas; Equidade em saúde; Assistência farmacêutica; Vulnerabilidade de saúde.

\section{Resumen}

La "transición epidemiológica" ha propiciado una creciente atención a las enfermedades crónicas y no transmisibles, pero las enfermedades desatendidas aún están presentes y su relación con las desigualdades socioeconómicas de la población es cada vez más evidente, tanto que se ha producido una conversión conceptual para llamarlas "pobreza enfermedades relacionadas". Es necesario revisar y discutir las características y desafíos de las políticas farmacéuticas brasileñas para las poblaciones afectadas por enfermedades relacionadas con la pobreza. Esta revisión de la literatura se llevó a cabo, con trabajos de los últimos 10 años que abordan el tema y la realidad brasileña. De los 272 artículos identificados, solo 43 publicaciones se incluyeron en este estudio. Los resultados fueron: (i) las dificultades de invertir en la investigación, desarrollo y producción de nuevos medicamentos para estas enfermedades; (ii) las características de las políticas de acceso a los medicamentos ya disponibles, sus avances y limitaciones; (iii) y cuestiones relacionadas con el derecho a la asistencia farmacéutica integral. Por lo tanto, para las terapias disponibles, la 
producción nacional y el financiamiento federal contribuyeron a garantizar el suministro. Las acciones de calificación asistida son necesarias y poco discutidas en los estudios de área.

Palabras clave: Enfermedades desatendidas; Equidad en salud; Servicios farmacéuticos; Vulnerabilidad sanitária.

\section{Introduction}

Despite the discussion on "neglected diseases" being debated since 1970s, the global pharmaceutical market's lack of interest in investing in medicines for developing countries' own diseases seems far from over (Academia Brasileira de Ciências, 2010). In recent years, there has been a conceptual conversion to denominate them as "poverty-related diseases" or simply "diseases of poverty", in addition to diseases such as tuberculosis, leprosy and malaria, for example, attention has focused on certain non-transmissible as well as to emphasize the relationship between these diseases and the socioeconomic inequalities of the population(Instituto Oswaldo Cruz, 2011; World Health Organization, 2012).

This scene is part of a market adaptation to the so-called global "epidemiological transition", characterized by a market decline in mortality due to acute transmissible diseases and a predominance of chronic conditions. In addition, there is the divestment of the pharmaceutical industry developing products to treat these diseases.

However, to view this picture as a simple unchanging result of the lack of industrial interest in the development of products that target diseases of poverty is to relegate vulnerable populations to their fate(Oliveira et al., 2006; Trouiller et al., 2001).

The ability of health policies to change this framework by reorienting scientific development priorities and pharmaceutical policies is crucial for success in controlling these diseases, which still account for a considerable percentage of the Brazilian burden diseases. These which may reach $24 \%$ of the total and to reach approximately 1 billion people per year (Schramm et al., 2004; WHO, 2017).

Few publications have analyzed this topic in recent years, since the public policy debate seems to be centered on discussing the impacts of pharmaceutical innovations on health financing, access to medicines for rare diseases, the impacts of medicalization and health judicialization, when the Brazilian society use of the judiciary to seek for the concretion of rights to health.

This research aims to review and discuss the characteristics, advances and challenges of Brazilian pharmaceutical policies for populations affected by poverty-related diseases.

\section{Methodology}

The study method was used as usually described in the scientific literature. It is characterized by the "mapping" activity of the subject investigated in order to verify the breadth and depth of the study field. Usually used for subjects that have multiple ways of approach in published works, not always with methodological harmony that is common on clinical trials for example. This type of review that allows the inclusion of studies with different methodologies, with greater potential for comprehensiveness and presentation of varied perspectives on a phenomenon is closer to what has been called by some Brazilian studies of integrative review(Kornis et al., 2014; Vargas et al., 2012).

As search criteria, the following descriptors and their English versions, previously selected in bases Medical Subject Headings (DeCS): "neglected diseases" or "control of transmissible diseases" or "endemic diseases" combined with the descriptors "pharmaceutical assistance", "Unified Health System", "public health policies", "national health programs" and "clinical research". Descriptors not included in Mesh and DeCS were also included: "diseases of poverty"; "poverty-related diseases".

The searches were conducted between June 2016 and April 2018, in the research portal of the Virtual Health Library 
(BVS), which covers a set of databases of interest to the theme, such as: Latin American Literature and (Lilacs), Medical Literature Analysis and Retrieval System Online (Medline) and Scientific Electronic Library Online (Scielo), the main sources of the selected studies.

The analysis steps followed the flow described in Figure 1, which then involved analysis of titles, abstracts, complete content and references check.

Figure 1 - Flowchart for trestment of studies during the review process.

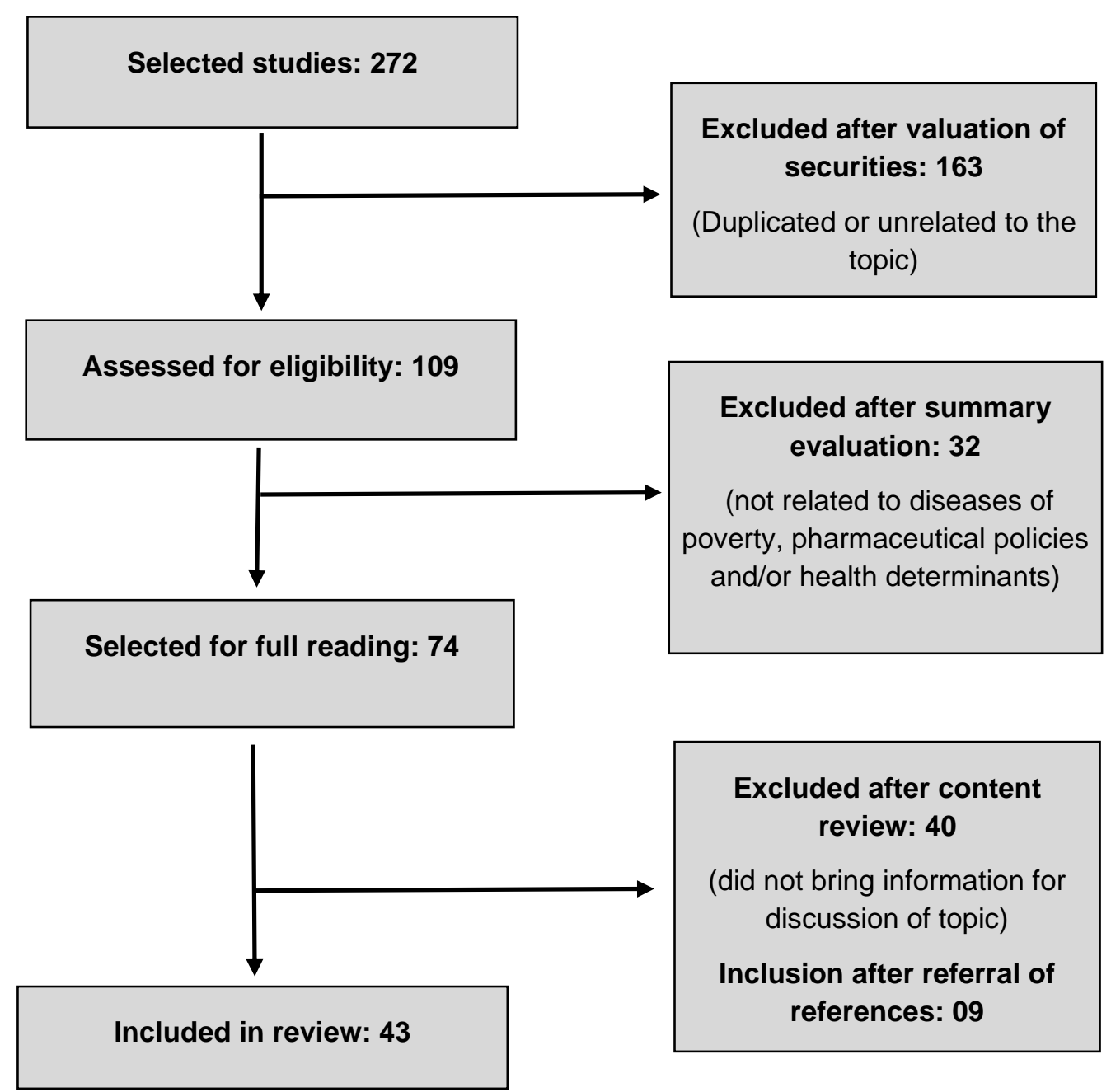

Source: Authors.

During the selection of studies, inclusion criteria were examined if they addressed the themes of poverty-related diseases and pharmaceutical care policies, with an approach in at least one of there three sub-themes: (i) research, development and production of new medicines for these diseases; (ii) policies for access to medicines already available; (iii) completeness of pharmaceutical assistance.

Exclusion criteria included publications that were more than 10 years old in order to obtain updated, duplicate, nonaccessible full-text analyzes, review, annals of congress, letters to the editor, papers that did not address any of the subtopics of this study and did not address Brazilian reality.

A total of 43 studies were included in this review, which were described in Table 1. Among the selected papers, 31 
were papers published in scientific journals, 05 post-graduation studies and 04 documents from institutions that addressed issues of poverty-related diseases, namely: Brazilian Institute of Science (ABC, 2010), Ministry of Health (Brasil, 2014), Medicines for Applied Economic Research (12).

Table 1 - Characterization of selected Works.

\section{Selected Works}

Type of work

Barreto et al (2011); Bastos (2006); Crispim et al (2014); De Paula et al (2009); DECIT (2010); Domingues et al (2005); Domingues e Teixeira (2013); Feijó e Sáfadi (2006); Gava et al (2010); Kornis et al (2014); Hochman (2009); Hochman (2009b); Hochman (2010); Hochman (2011); Jamal e Moherdaui (2007); Luzia et al (2017); Marco et al (2012); Nascimento (2011); Oliveira et al (2006); Osorio-de-Castro et al (2009); Penna et al (2013); Perreira e Freitas (2008); Pontes (2009);

Original article published in scientific journal Pontes et al (2010); Raw e Higashi (2008); Santana e Leite (2017); Santana et al (2017); Santos (2007); Santos et al (2012); Silva e Nicoletti (2013); Silveira e Junior (2011); Souza (2005); Vieira (2010); Waldman (2011);

Resende (2013); Witzel (2009); Magalhães (2010); Muniz (2013); Postgraduate work in a strict Torres (2013); sense

ABC (2010); Brasil (2014); DNDi (2012); Garcia (2011); Study/Institutional Report

Source: Authors.

\section{Results and Discussion}

Of 272 publications that were analyzed, 43 of them met the criteria and were analyzed in detail by the authors. The main theses and narratives addressed in the works were organized in three parts that are summarized schematically in Figure 2 and described in detail in the following sections. 
Figure 2 - Central ideas captured in the analyzed literature.

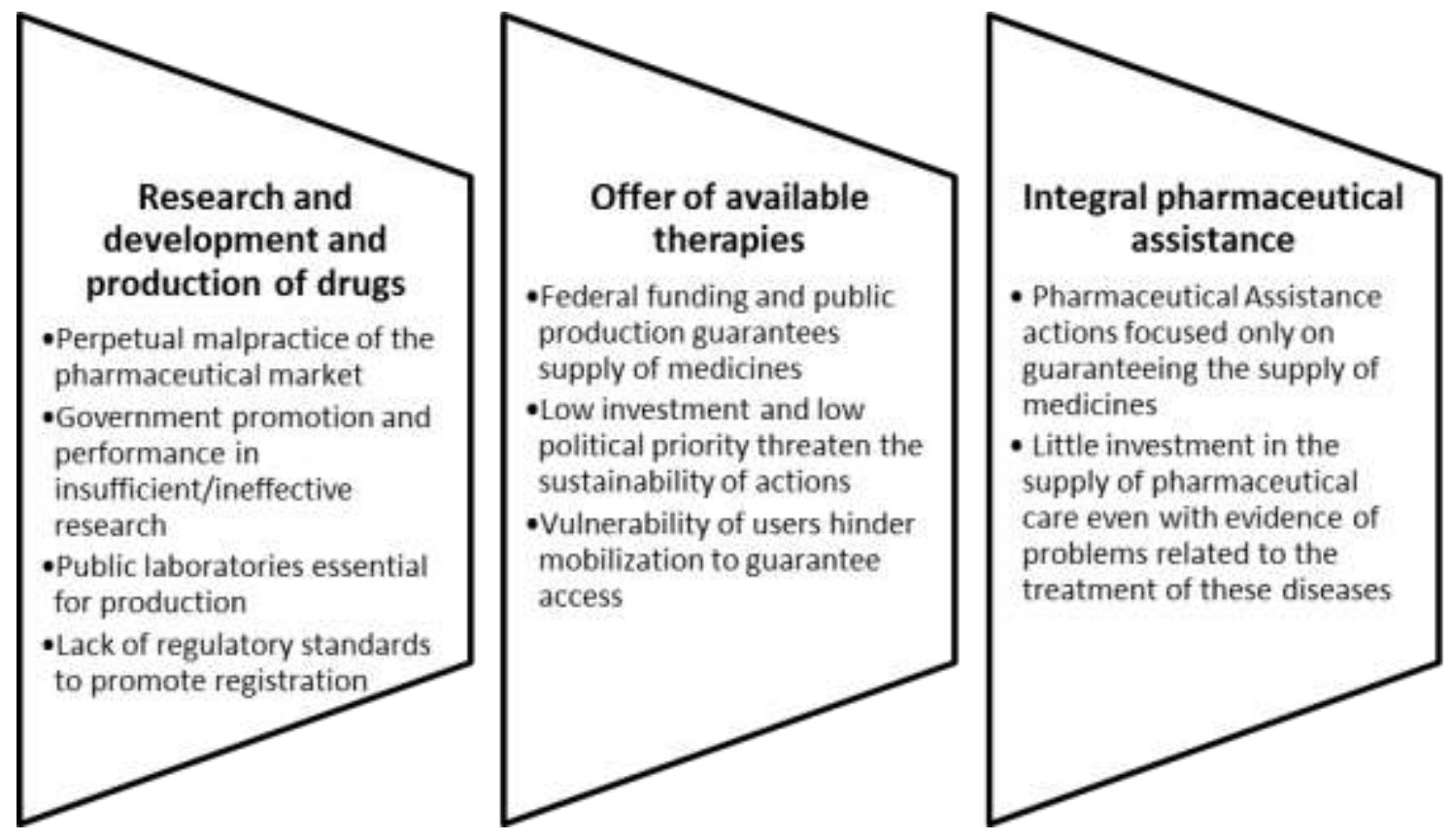

Source: Authors.

\section{Research, development and production of pharmaceuticals: right denied by the market}

Currently led by large global corporations, pharmaceutical drug research and development (R\&B) activities have historically been concentrated in a few developed countries. Although there is a relative diffusion tendency of the area for some developing countries (Kornis et al., 2014; Vargas et al., 2012).

It is estimated that the share of investments in clinical trials in other non-traditional centers such as Brazil, India and China has gone from 29\% in 2001 to more than 50\% in 2011, with a higher concentration in phase III tests, longer with more participants, more expensive, but with lower density of knowledge involved (Bastos, 2006; Gomes et al., 2012).

Despite this insertion, the research of new medicines does not meet the real needs of society. This is clear in recent decades, about $90 \%$ of health problems receive only $10 \%$ of investments in medicines research, or when it is found that in the period between 1975 and 2004, only 1\% the 1,535 new registered medicines were for tropical diseases or related to poverty, even accounting for approximately $12 \%$ of the global burden of diseases (Bastos, 2006; Chirac \& Torreele, 2006; F. L. A. dos Santos et al., 2012). In Brazil, 4\% of clinical trials with medicines in the country are dedicated to improving treatment for diseases of poverty, most of them financed by public resources, in contrast to other studies with a predominance of private financing (Santana \& Leite, 2016).

It is therefore imperative that governments in developing countries take the lead in R\&D of medicines for diseases of poverty. Protagonism that was often assumed by developed countries, often lined to issues of colonization and military involvement that culminated in the discovery of medicines.

Malaria is a good example of this, as its main medicines were developed following US government research because of the large numbers of casualties, in World War II, malaria was responsible for more than 21,000 hospital admissions, including hospitalizations for combat wounds with 17,000 cases (Bastos, 2006; Campos, 1999).

The external dependence and poor Brazilian performance in the research of new medicines is a constant narrative in the articles. In general, the activities of the national industry are not centered on the R\&D process, since from its conception they are associated with meeting the demand for basic pharmaceutical assistance and covering the gaps in the national 
production of essential medicines (Oliveira et al., 2006). Even with the government's encouragement to strengthen the national industry with specific programs of the National Bank for Social Development, there is still little investment in the R\&D area, in terms of the international standard of that invest on average twice the national pharmaceutical industry (Kornis et al., 2014; Vargas et al., 2012). Other studies that analyzes the relationship between laboratories and innovation for neglected diseases warn to the great productive potential of official laboratories and their strategic role for access to medicines for these diseases, but highlight their little contribution in research and innovation (Bastos, 2006; F. L. A. dos Santos et al., 2012).

In order to encourage the development of research, the Ministry of Health since 2003 has launched thematic edicts for neglected diseases that already surpass the accumulated value about 22 million US dollars (USD) (Departamento de Ciência e Tecnologia do Ministério da Saúde, 2010). The Ministry of Science, Technology and Innovation has also increased incentives, which are around USD 19 million per year (F. Pontes, 2009). Although laudable, the initiative of the Brazilian government is still far from solving the problem of the lack of medicines, since the incentives are diffuse and insufficient for the development of new drugs. It is estimated that the cost varies from USD 11 to 44 million for improved treatments and from USD 110 to 165 million for a new molecular entity (Academia Brasileira de Ciências, 2010; Iniciativa Medicamentos para Doenças Negligenciadas, 2012).

Based on work developed over the past decade, the Drugs for Neglected Diseases Initiative has published a report on actions it deems essential in the long run to increase R\&D in these diseases: open innovation and pro-access intellectual property management, sustainable financing mechanism, coordination of R\&D with the commitment of endemic countries and innovative regulatory proccess (Iniciativa Medicamentos para Doenças Negligenciadas, 2012).

Despite the lack of investment in innovation, the existence of a network of public laboratories is an important strength of the country, often the only way to produce medicines for diseases of poverty (Garcia, 2011). Proof of this is a notable Brazilian path towards self-sufficiency in the production of vaccines by public laboratories initially motivated by the lack of continuity of private production and the lack of interest of the market in these products (Raw \& Higashi, 2008). Technological park modernization programs, as well as investment in productive development partnerships, are pointed out as strategies to strengthen the production of medicines for diseases of poverty, despite the lower participation of these drugs in the portfolio of official laboratories (Magalhães, 2010; Oliveira et al., 2006; Resende, 2013).

In the regulatory area, the profile of so-called new medicines registered in Brazil is not characterized as real innovations and do not meet local needs. Registered products mostly refer to drugs for chronic diseases and none of the drugs were intended for diseases of poverty. The potential benefit of the strategy of prioritizing the analysis and granting registration of these drugs in the country as of 2007 for diseases of interest to SUS (Gava et al., 2010) is highlighted, but did not has impacted in this area.

A comparative study of regulatory regulations in Brazil, the United States and Europe, analyzed that, unlike the other international agencies, Brazil did not develop specific regulatory norms to promote the registration of drugs with less commercial interest. There is no regulation of orphan drugs or incentive to register medicines for pediatric populations, for example, which may further hamper the availability of medicines for diseases in poverty. Complex incorporation rules, failures in the planning of production demand for SUS care, and little articulation with Latin American countries, discourages investments in the production of these drugs, even in official laboratories or in partnerships with them (Luiza et al., 2017; Santana et al., 2017).

\section{Offer of available therapies: guaranteed right?}

If there is a large share of market responsibility for the lack of innovation for diseases of poverty, it is not possible to attribute the same fault to the mechanisms of access to medicines already available. It is the duty of governments to guarantee 
access to health care for vulnerable populations (de Paula et al., 2009; Souza, 2005).

Lack of access to medicines can directly influence the lives of families. It stands out as the health component that contributes most to the impoverishment of Brazilian families, responsible for $60.9 \%$ of the increase of households below the poverty line (Boing et al., 2014).

Positive results from investments in access to medicines for diseases of poverty have been demonstrated in some areas. Proof of this is the success of the National Immunization Program (NIP), which has achieved one of the highest rates of immunization coverage in the world without the use of coercive strategies, as initially occurred in the notorious "vaccine revolt" and with control of communicable diseases. Between 1980 and 2007, tetanus deaths fell by $81 \%$ and pertussis deaths declined by $95 \%$, no deaths were recorded by diphtheria or measles in 2007; the country has received international certification of eradication of diseases such as smallpox and polio and control of diseases such as mumps and rubella. Most of the authors attribute these results mainly to the sustainability characteristics of the NIP actions, the investment in the national production of vaccines and the formation of a vaccine culture in the country (Barreto et al., 2011; Hochman, 2011).

The expansion of access to antimicrobials has also, to a certain degree, reduced or eliminated certain diseases, as observed for example in the Bouba Eradication Program in Brazil focused on the use of penicillin under President Juscelino Kubitschek (Hochman, 2009a; Muniz, 2012). Others have drastically reduced new cases and are on the brink of elimination, such as schistosomiasis, filariasis, meningococcal disease and Chagas' disease (Barreto et al., 2011; Brasil. Ministério da Saúde. Secretaria de Vigilância em Saúde, 2014). Other diseases, such as tuberculosis and leprosy, although they still have a high number of cases, are steadily decreasing year by year, especially after the efficient decentralization of routine treatment, promotion of the monitoring of the use by the health team and the structuring of the system of health surveillance (Pen et al., 2013; J. Santos, 2007).

Much of the literature highlights the lack of political priority, the discontinuation of endemic disease control strategies, and the weak structuring of surveillance and health care actions, as the main barriers to control and eliminate some diseases of poverty. The shortage of resources and the delay in the institutionalization of a national program to control Chagas' disease favored its high incidence until the 1990s (Silveira \& Pimenta Junior, 2011). The slowness of the state response to epidemic control actions was decisive for Brazil to be the last Latin American country to eliminate smallpox (Hochman, 2009b). And the attempt to hide the real picture of the Spanish flu epidemic and little state action has mainly affected the poorest working people in port cities like Salvador (Souza, 2005), a city located in northeastern Brazil. Constant changes in strategies to combat mosquito-borne epidemics, ranging from previous use of chloroquine salt, use of insecticides to combat vectors, distribution of mosquito nets, increased distribution and medications or more recent educational campaigns result in the floating 300,000 cases year of malaria and 1 million annual cases of dengue (Barreto et al., 2011; Hochman, 2010; J. S. Silva et al., 2008).

Currently, access to medicines for diseases of poverty occurs mainly with federal funding, through the NIP and the Strategic Component of Pharmaceutical Care, the latter with an average investment of around USD 15 million/year. This is a very low value when compared to USD 200 million spent on VIH/SIDA antiretroviral drugs or a large USD 1 billion for diseases of the Specialized Component of Pharmaceutical Care (Garcia, 2011; Vieira, 2010).

The cost-effectiveness of these medicines is explained by the involvement of official public laboratories that account for more than $80 \%$ of the production of medicines for diseases of poverty. In 1992, for example, approximately $60 \%$ of all PNI vaccines were imported; in 2002, 70\% were produced in Brazil and in 2012 almost 96\% were already produced in the country and a large part by public laboratories of the Oswaldo Cruz Foundation and Instituto Butantan (Barreto et al., 2011; Domingues \& Teixeira, 2013; Raw \& Higashi, 2008).

Directly pursuing this search for the economy and going against the national policies of access to medicines is the 
phenomenon of health judicialization in Brazil, a controversial issue among specialists in public health and health law, but nowadays is configured as a way of access to medicines in the country (Hunt \& Khosla, 2008; Vargas-Peláez et al., 2014).

At this point, one can observe more evidence of the vulnerability of those affected by diseases of poverty, when a review of the literature has identified that the majority of the Brazilian lawsuits for access to medicines come from people who have the condition to pay private lawyers and destined to the care of chronic conditions, with little or no observation of actions for access to medicines for infectious or poverty-related diseases. It is true that the shortage of products and the low interference of the pharmaceutical industry explains this result, but it is necessary to emphasize that despite the launching of new drugs internationally - such as benzonidazole in soluble formulations (Chagas disease), miltefosine (leishmaniases) or bedaquiline (tuberculosis), and no incorporation pressure is observed, as is the case with new antineoplastics or immunobiologicals, for example (Torres, 2013).

\section{Integral pharmaceutical services: a negligence?}

Another point worth mentioning is the right to full pharmaceutical assistance for diseases of poverty. The integrality of care to the users of medicines is only established when the latter is guaranteed the opportunity of adequate dispensing and guidance of a professional pharmacist who can even monitor their treatment, articulating with other professionals and health services for the success in the care.

Perhaps as an inheritance of a campaigning policy, the focus of actions of pharmaceutical services to combat diseases of poverty was limited to the acquisition and distribution of vaccines and other essential medicines, which is already an achievement, but aspects related to the monitoring of effectiveness and safety of medicines still need advancement.

Even with the introduction of the concept of pharmaceutical care, in an extended perspective of care of the user's drug needs, reviews of the literature show that the Brazilian initiatives in this area follow a North American and European trend that focuses on the care of the elderly and those with chronic conditions such as hypertension and diabetes. However, few countries besides Brazil could develop both in the pharmaceutical care of diseases of poverty, contributing to the control and elimination of these diseases, since many of them are characterized by complex treatments with a high number of interactions and adverse reactions that they need of constant monitoring and permanent incentive to join (Pereira \& Freitas, 2008; Witzel, 2009), besides preventing medications errors.

In tuberculosis, for example, for the most effective control of the disease in the country, it is necessary to strengthen the approach of supervised treatment, invest in monitoring therapy and reduce dropout rates, and invest in the monitoring of cases of VIH coinfection that doubles the difficulties of success of pharmacotherapy (Jamal \& Moherdaui, 2007; J. Santos, 2007). In leprosy, increased access to drug treatment is contributing to the reduction of disease rates, but the prevention of abandonment of the treatment and drug resistance are the greatest challenges for health teams (Pen et al., 2013; B. N. Santos et al., 2015).

A study that carried out pharmacotherapeutic follow-up of 32 patients with Chagas' disease in Ceará, in northeastern Brazil, in 2010 also observed that the excess of adverse reactions to benzonidazole in the evaluated patients (87.5\%) led to the abandonment of treatment by about $30 \%$ of the participants, a serious problem when we consider that no other treatment option is available in the country (V. M. O. De Pontes et al., 2010). The study concludes that the pharmacotherapeutic follow-up of these patients is of great relevance in the prevention and early detection of adverse drug reactions. Silva and Nicoletti (E. Silva \& Nicoletti, 2013) also point out problems related to resistance due to misuse of antimalarials, toxicity and efficacy failures in the treatment of schistosomiasis, and the need for greater monitoring of pharmacotherapy of Leishmaniasis, related to hepatic, renal and cardiac damage.

Monitoring adverse reactions and improving pharmacovigilance actions are also underdeveloped activities, especially 
when referring to diseases of poverty. Despite the low participation of pharmacists in vaccination campaigns, professionals traditionally involved in pharmacovigilance actions, PNI and Brazilian Health Regulatory Agency increasingly have seen as a necessity the improvement of post-vaccination monitoring processes that, even with passive surveillance limitations, have obtained successfully in the identification of vaccines and more reatogenic lots, of events little known or not described in the literature (Domingues et al., 2012; Waldman et al., 2011).

Analysis of the actions of pharmaceutical services for malaria in the northern region of the country proposed that tools for planning and monitoring pharmaceutical actions and services be incorporated into health services for diseases of poverty. The study lists 25 indicators related to prescription, dispensation and adherence issues that can be used to qualify this services (Osorio-de-Castro et al., 2009).

Qualifying pharmaceutical care with a look at equity is critical to improving health outcomes and overcoming diseases of poverty. However, in certain aspects, it can be seen that there is an inequity of investments in state actions. While we verify the existence of a specific protocol for pharmaceutical care in STD/ SIDA (Brasil. Ministério da Saúde. Secretaria de Vigilância em Saúde \& BRASIL. Ministério da Saúde. Secretaria de Vigilância em Saúde. Departamento de DST Aids e Hepatites Virais., 2010), providing for pharmaceutical care actions, carried out individually or collectively, we do not observe the same treatment in programs for diseases of poverty that do not even regulate the presence of pharmacists, the exception of the leprosy program, but with the mandatory linked more to the dispensation of thalidomide than to the care of patients themselves (Brasil. Ministério da Saúde. Agência Nacional de Vigilância Sanitária, 2011; Villarinho et al., 2013).

\section{Conclusion}

Deficiencies and strengths in national pharmaceutical policies are highlighted in the researched literature. The field of innovation is dependent and hostage of the perennial disinterest of the global pharmaceutical market, with poor SUS investment with weak performance especially in the area of research of new drugs. The existence of public laboratories for the production of the available alternatives and the federal financing are strengths of the policies, but they seem to have their sustainability threatened by the little investment and little capacity of political mobilization of the users affected by these diseases, either for guarantee of the offer, or by the qualification of the assistance. Significant advances achieved, such as stimulating national production and guaranteeing federal funding of these medicines, have contributed decisively to reducing cases of poverty, but issues such as monitoring the quality of treatments offered and ensuring pharmaceutical care can not continue to be neglected. The low number of studies on the theme and the difficulty of evaluating the quality of these in the selection for a narrative review are limitations of this work. Additional studies that focus on specific themes of health regulation, new strategies to promote drug research and development, analyze micro processes of accessibility to these drugs and the pharmacotherapeutic results of care tend to qualify the exploration of the topic, due to its scarcity.

\section{References}

Academia Brasileira de Ciências. (2010). Doenças neglicenciadas.

Barreto, M. L., Teixeira, M. G., Bastos, F. I., Ximenes, R. A., Barata, R. B. \& Rodrigues, L. C. (2011). Successes and failures in the control of infectious diseases in Brazil: Social and environmental context, policies, interventions, and research needs. The Lancet, 377(9780), 1877-1889. https://doi.org/10.1016/S0140-6736(11)60202-X

Bastos, V. D. (2006). Laboratórios Farmacêuticos Oficiais e Doenças Negligenciadas: Perspectivas de Política Pública. Revista Do BNDES, 13(25), 269-298. Boing, A. C., Bertoldi, A. D., Posenato, L. G. \& Peres, K. G. (2014). The influence of health expenditures on household impoverishment in Brazil. Revista de Saúde Pública, 48(5), 797-807. https://doi.org/10.1590/S0034-8910.2014048005113

Brasil. Ministério da Saúde. Agência Nacional de Vigilância Sanitária. (2011). Resolução no 11, de 22 de março de 2011. Dispõe sobre o controle da substância Talidomida e do medicamento que a contenha. Http://Bvsms.Saude.Gov.Br/Bvs/Saudelegis/Anvisa/2011/Res0011_21_03_2011.Html.

Brasil. Ministério da Saúde. Secretaria de Vigilância em Saúde. (2014). Saúde brasil 2013: uma análise da situação de saúde e das doenças transmissíveis 
realcionadas a pobreza.

Brasil. Ministério da Saúde. Secretaria de Vigilância em Saúde \& BRASIL. Ministério da Saúde. Secretaria de Vigilância em Saúde. Departamento de DST Aids e Hepatites Virais. (2010). Protocolo de assistência farmacêutica em DST/HIV/Aids: recomendações do Grupo de Trabalho de Assistência Farmacêutica. In Disponível em: http://bvsms.saude.gov.br/bvs/publicacoes/protocolo_assistencia_farmaceutica_aids.pdf.

Campos, A. L. V. de. (1999). Combatendo nazistas e mosquitos: militares norte-americanos no Nordeste brasileiro (1941-45). História, Ciências, SaúdeManguinhos, 5(3), 603-620. https://doi.org/10.1590/S0104-59701999000100004

Chirac, P. \& Torreele, E. (2006). Proportion of new drugs developed over the period from 1975 to 2004 that were for neglected tropical diseases and tuberculosis. Lancet, 12, 1560-561.

de Paula, P. A. B., Alves, T. N. P., Vieira, R. D. C. P. A. \& de Souza, A. I. S. (2009). Política de medicamentos: Da universalidade de direitos aos limites da operacionalidade. Physis, 19(4), 1111-1125. https://doi.org/10.1590/S0103-73312009000400011

Departamento de Ciência e Tecnologia do Ministério da Saúde. (2010). Doenças negligenciadas: estratégias do Ministério da Saúde. Revista de Saude Publica, 44(1), 200-202. https://doi.org/10.1590/S0034-89102010000100023

Domingues, C. M. A. S. \& Teixeira, A. M. D. S. (2013). Coberturas vacinais e doenças imunopreveníveis no Brasil no período 1982-2012: avanços e desafios do Programa Nacional de Imunizações. Epidemiol. Serv. Saúde, 22(1), 9-27. https://doi.org/10.5123/S1679-49742013000100002

Domingues, C. M. A. S., Teixeira, A. M. D. S. \& Carvalho, S. M. D. (2012). National immunization program: Vaccination, compliance and pharmacovigilance. Revista Do Instituto de Medicina Tropical de Sao Paulo, 54(SUPPL.18), 22-27. https://doi.org/10.1590/S0036-46652012000700009

Garcia, L. P. E. A. (2011). Epidemiologia das doenças negligenciadas no Brasil e gastos federais com medicamentos. In IPEA Textos para discussão.

Gava, C. M., Bermudez, J. A. Z. \& Pepe, V. L. E. (2010). Novos medicamentos registrados no Brasil: podem ser considerados como avanço terapêutico? Ciência \& Saúde Coletiva, 15, 3403-3412. https://doi.org/10.1590/S1413-81232010000900015

Gomes, R. D. P., Pimentel, V. P., Landim, A. B. \& Pieroni, J. P. (2012). Ensaios clínicos no Brasil: competitividade internacional e desafios.

Hochman, G. (2009a). “O Brasil não é só doença”: o programa de saúde pública de Juscelino Kubitschek. História, Ciências, Saúde-Manguinhos, 16, 313331. https://doi.org/10.1590/S0104-59702009000500015

Hochman, G. (2009b). Priority, invisibility and eradication: the history of smallpox and the Brazilian public health agenda. Medical History, 53(2), 229-252. https://doi.org/10.1017/S002572730000020X

Hochman, G. (2010). O sal como solução? políticas de saúde e endemias rurais no Brasil (1940-1960). Sociologias, 12(24), 158-193. https://doi.org/10.1590/S1517-45222010000200007

Hochman, G. (2011). Vacinação, varíola e uma cultura da imunização no Brasil. Ciência \& Saúde Coletiva, 16(2), 375-386. https://doi.org/10.1590/S141381232011000200002

Hunt, P. \& Khosla, R. (2008). The human right to medicines. Sur - International Journal of Human Rights, 8, 99-115.

Iniciativa Medicamentos para Doenças Negligenciadas. (2012). Porque é necessária uma convenção sobre P\&D essencial em saúde? Disponível Em: Http://Www.Dndi.Org/Images/Stories/Advocacy/Dndi_policy_port_27_04_2012.Pdf.

Instituto Oswaldo Cruz. (2011). Nota Tecnica $n^{\circ} 1$ de 2011: Embasamento técnico e sugestões para ações de controle das doenças da pobreza no programa de erradicação da pobreza extrema no Brasil.

Jamal, L. F. \& Moherdaui, F. (2007). Tuberculose e infecção pelo HIV no Brasil: magnitude do problema e estratégias para o controle. Revista de Saúde Pública, 41, 104-110. https://doi.org/10.1590/S0034-89102007000800014

Kornis, G. E. M., Braga, M. H. \& Paula, P. A. B. de. (2014). Transformações recentes da indústria farmacêutica: um exame da experiência mundial e brasileira no século XXI. Physis: Revista de Saúde Coletiva, 24(3), 885-908. https://doi.org/10.1590/S0103-73312014000300012

Luiza, V. L., Chaves, G. C., Barboza, T. M. T., Gonçalves, L. de P. B., Stobbaerts, E. G., Luiza, V. L., Chaves, G. C., Barboza, T. M. T., Gonçalves, L. de P. B. \& Stobbaerts, E. G. (2017). Desafios de uma parceria para o desenvolvimento de produtos: o caso de um tratamento para malária. Ciência \& Saúde Coletiva, 22(7), 2197-2211. https://doi.org/10.1590/1413-81232017227.04042017

Magalhães, J. L. De. (2010). Estratégia Governamental para Internalização de Fármacos \& Medicamentos em Doenças Negligenciadas. Universidade Federal do Rio de Janeiro.

Muniz, É. S. (2012). “Basta aplicar uma injeção?”: concepções de saúde, higiene e nutrição no Programa de Erradicação da Bouba no Brasil, 1956-1961. História, Ciências, Saúde-Manguinhos, 19(1), 197-216. https://doi.org/10.1590/S0104-59702012000100011

Oliveira, E. A. de, Labra, M. E. \& Bermudez, J. (2006). A produção pública de medicamentos no Brasil: uma visão geral. Cadernos de Saúde Pública, 22(11), 2379-2389. https://doi.org/10.1590/S0102-311X2006001100012

Osorio-de-Castro, C. G. S., Chaves, G. C., Miranda, E. S. \& Suárez-mútis, M. C. (2009). A proposal for an evaluation model of pharmaceutical services for malaria. 25(9), 2075-2082.

Pen, M., Grossi, M. \& Penna, G. (2013). Country profile: leprosy in Brazil. Lepr Rev, 84(3), 308-315.

Pereira, L. R. L. \& Freitas, O. De. (2008). A evolução da Atenção Farmacêutica e a perspectiva para o Brasil. Revista Brasileira de Ciências Farmacêuticas, 
44(4), 601-612. https://doi.org/10.1590/S1516-93322008000400006

Pontes, V. M. O. De, Souza Júnior, A. S. De, Cruz, F. M. T. Da, Coelho, H. L. L., Dias, A. T. N., Coêlho, I. C. B. \& Oliveira, M. D. F. (2010). Reações adversas em pacientes com doença de Chagas tratados com benzonidazol, no Estado do Ceará. Revista Da Sociedade Brasileira de Medicina Tropical, 43(2), 182-187. https://doi.org/10.1590/S0037-86822010000200015

Pontes, F. (2009). Doenças negligenciadas ainda matam 1 milhão por ano no mundo. Inovação Em Pauta, 6, 69-73. https://doi.org/10.1590/S003489102010000100023

Raw, I. \& Higashi, H. G. (2008). Auto-suficiência e inovação na produção de vacinas e saúde pública. Estudos Avançados, 22(64), 155-170.

Resende, K. S. (2013). As parcerias para o desenvolvimento produtivo (PDPS) e o estímulo à inovação em instituições farmacêuticas públicas e privadas brasileiras. Escola Nacional de Saúde Publica Sergio Arouca.

Santana, R. S. \& Leite, S. N. (2016). Prioridades da pesquisa clínica com medicamentos no Brasil e as doenças da pobreza. Rev Panam Salud Publica, 40(5), $355-361$.

Santana, R. S., Lupatini, E. de O. \& Leite, S. N. (2017). Registro e incorporação no SUS: Barreiras de acesso a medicamentos para doenças da pobreza? Ciencia \& Saude Coletiva, 22(5), 1417-1428.

Santos, B. N., Queiroz, L. B. \& Sacchetim, S. C. (2015). Percepção da equipe de saúde responsável pela assistência aos portadores de Hanseníase acerca do abandono do tratamento pelos pacientes. Revista Educação Em Saúde, 1(2), 96-107.

Santos, F. L. A. dos, Lyra, M. A. M., Alves, L. D. S., Ramos, K. E., Silva, D., Rolim, L. A. \& Rolim-Neto, P. J. (2012). Pesquisa , desenvolvimento e inovação para o controle das doenças negligenciadas. Revista de Ciências Farmacêuticas Básica e Aplicada, 33(1), 37-47.

Santos, J. (2007). Resposta brasileira ao controle da tuberculose. Revista de Saúde Pública, 41, 89-93. https://doi.org/10.1590/S0034-89102007000800012

Schramm, J. M. D. A., Oliveira, A. F. De, Leite, I. D. C., Valente, J. G., Gadelha, Â. M. J., Portela, M. C. \& Campos, M. R. (2004). Transição epidemiológica e o estudo de carga de doença no Brasil. Ciência \& Saúde Coletiva, 9(4), 897-908. https://doi.org/10.1590/S1413-81232004000400011

Silva, E. \& Nicoletti, M. (2013). Controle e Tratamento das doenças negligenciadas: visão da situação atual. Revista Saúde, 4742(11), 65-81.

Silva, J. S., Mariano, Z. D. F. \& Scopel, I. (2008). A dengue no Brasil e as políticas de combate ao Aedes aegypti: da tentativa da erradicação ás políticas de controle. Revista Brasileira de Geografia Médica e Da Saúde, 3(6), 163-175.

Silveira, a. C. \& Pimenta Junior, F. (2011). A inserção institucional do controle da doença de Chagas. Rev. Soc. Bras. Med. Trop., 44(Suplemento II), 19-24. https://doi.org/10.1590/S0037-86822011000800004

Souza, C. M. C. De. (2005). A gripe espanhola em Salvador, 1918: cidade de becos e cortiços. História, Ciências, Saúde-Manguinhos, 12(1), 71-99. https://doi.org/10.1590/S0104-59702005000100005

Torres, I. D. C. (2013). Judicialização do acesso a medicamentos no Brasil: uma revisão sistemática. Universidade Federal da Bahia.

Trouiller, P., Torreele, E., Olliaro, P., White, N., Foster, S., Wirth, D. \& Pécoul, B. (2001). Drugs for neglected diseases: A failure of the market and a public health failure? Tropical Medicine and International Health, 6(11), 945-951. https://doi.org/10.1046/j.1365-3156.2001.00803.x

Vargas-Peláez, C. M., Rover, M. R. M., Leite, S. N., Rossi Buenaventura, F. \& Farias, M. R. (2014). Right to health, essential medicines, and lawsuits for access to medicines - A scoping study. Social Science \& Medicine, 121, 48-55. https://doi.org/10.1016/j.socscimed.2014.08.042

Vargas, M., Gadelha, C. A. G., Costa, L. S. \& Maldonado, J. (2012). Inovação na indústria química e biotecnológica em saúde: Em busca de uma agenda virtuosa. Revista de Saude Publica, 46(SUPPL.1), 37-40. https://doi.org/10.1590/S0034-89102012000700006

Vieira, F. S. (2010). Assistência farmacêutica no sistema público de saúde no Brasil. Revista Panamericana de Salud Pública, 27(2), 149-156. https://doi.org/10.1590/S1020-49892010000200010

Villarinho, M. V., Padilha, M. I., Berardinelli, L. M. M., Borenstein, M. S., Meirelles, B. H. S. \& Andrade, S. R. De. (2013). Políticas públicas de saúde face à epidemia da AIDS e a assistência às pessoas com a doença. Revista Brasileira de Enfermagem, 66(2), 271-277. https://doi.org/10.1590/S003471672013000200018

Waldman, E. A., Luhm, K. R., Monteiro, S. A. M. G. \& Freitas, F. R. M. de. (2011). Vigilância de eventos adversos pós-vacinação e segurança de programas de imunização. Revista de Saúde Pública, 45(1), 173-184. https://doi.org/10.1590/S0034-89102011000100020

WHO. (2017). Integrating Neglected tropical diseases into global health and development: fourth WHO report on neglected tropical diseases. In World Health Organization.

Witzel, M. D. R. F. (2009). Produção científica brasileira na área de atenção farmacêutica entre 1990 e 2007. Universidade de São Paulo.

World Health Organization. (2012). Global report for research on infectious diseases of poverty. 